\title{
MAP2K2 Gene Mutation
}

National Cancer Institute

\section{Source}

National Cancer Institute. MAP2K2 Gene Mutation. NCI Thesaurus. Code C153256.

A change in the nucleotide sequence of the MAP2K2 gene. 